\title{
Sustaining Teachers' Organizational Commitment: A Glimpse on Spiritual Intelligence Paradigm
}

\author{
Kazeem Olanrewaju Ogunsola \\ International Islamic University Malaysia, qmasjid@yahoo.com \\ Rodrique Ancelot Harvey Fontaine \\ International Islamic University Malaysia \\ Mohammad Tahir Jan \\ International Islamic University Malaysia
}

\begin{abstract}
This paper examined the relationship between spiritual intelligence (SQ) and organizational commitment (OC) among employees. Consistent with Multiple Intelligence Theory (MI), 510 teachers were drawn through a list-based simple random sampling technique in the Peninsular areas of Malaysia. Hypothesis was tested with structural equation modeling (SEM) and the structural model was assessed through renowned GOF indices. Findings revealed that SQ relates significantly positive with OC, such that spiritually intelligent employees are more obliged towards workplace activities. GOF indices showed $\chi^{2} / d f$ ratio $(997.341 / 547)=$ 1.823, RMSEA (0.057), and CFI (0.903), providing empirical support for the hypothesized structural model. The study outcomes are promising. Theoretically, it contributes to organizational behavior research regarding the influence of spiritual resources and virtues on employees' behavior. The study has implications for HR policies such as compensation and motivation. Spiritual intelligence aids employees to see beyond the material aspects of the workplace. Hence, they are better inspired when HR managers augment HR policies with SQ components. Practically, employees are more productive, creative, and resourceful when performing organizational activities. Therefore, the study provides indication on how employees can consider work-related activities as a quest worth achieving. Within this process, lies the opportunity to experience spiritual consciousness which stimulates their personal growth and development. The study is limited in a number of ways. It is cross-sectional, purely quantitative, and has its social-demographic factors controlled.
\end{abstract}

Keywords: Organizational commitment (OC), Spiritual intelligence (SQ), Employees, Malaysia

\section{Introduction}

Interest in organizational commitment is growing due to perceived psychological attachment of individuals to their organization (Jaros \& Culpepper, 2014; Meyer, Stanley, Herscovitch, \& Topolnytsky, 2002). More strikingly, is the significant impact of employees' commitment on other outcomes, such as on turnover, citizenship behaviours, performance, and absenteeism (Dixit \& Bhati, 2012; Ko, Price, \& Mueller, 1997). Researchers note that organizations are faced with the challenges of sustaining employees' organizational commitment (Castro-Casal, Vila-Vázquez, \& Pardo-Gayoso, 2019; Ogunsola, Fontaine, \& Jan, in press). This is due to the $21^{\text {st }}$ century business environment which is increasingly becoming more competitive.

Organizations are not only competing to acquire more customers or investments, they are also in the race to recruit, select or retain their best employees to drive their business agenda. Studies show that no organization can function at its peak without committed employees (Dam, Vuuren, \& Kemps, 2017). Freeman (1983) likens employees as stakeholders and describe as "those groups without whose support the organization would cease to exist" (p. 89). Therefore, their sustained organizational commitment plays vital role on the actions, objectives or policies of every organization (James, Lee, \& Sybille, 2002). Given this backdrop, literature indicates that spiritual intelligence can be potentially beneficial to a number of organizational variables (Antunes, Silva, \& Oliveira, 2017; Mahmood, Arshad, Ahmed, Akhtar, \& Khan, 2018). Studies on spiritual intelligence reported its positive relationship with organizational outcomes, such as organizational learning (Pluta \& Rudawska, 2016); organizational sustainability (Akhtar, Arshad, Mahmood, \& Ahmed, 2015); organizational citizenship behaviour (Hunsaker, 2016), job satisfaction (Roof, Bocarnea, \& Winston, 2017), leadership performance (Ramachandaran, Krauss, Hamzah, \& Idris, 2017), business management (Fontaine, 2018), and leadership performance (Osman-Gani \& Hassan, 2018). 
In this regard, it is reasonable to assume that spiritual intelligence will enhance employees' emotional stability, boost morale, and increase organizational commitment. The study is conducted among teachers' in Malaysia. There seems to be dearth of research investigating Malaysian teachers' organizational commitment in the light of SQ and its dimensions. Most of the existing studies on spiritual intelligence and organizational commitment were conducted outside Malaysia (Awais, Malik, \& Qaisar, 2015; Kalantarkousheh, Sharghi, Soleimani, \& Ramezani, 2014; Kaur \& Singh, 2013; Marghzar \& Marzban, 2018; Upadhyay, 2017). To this end, this study seeks to address some lacuna existing in the literature. Hence, it fills both theoretical and contextual gaps. Its main objective is to examine the relationship between SQ \& OC viz-a-viz Malaysian teachers. It is hoped that the outcome will be generalizable to every service employee.

\section{Literature Review}

\section{Organizational Commitment}

Researchers define organizational commitment as the "extent to which an individual identifies and is involved with his or her organization and /or is unwilling to leave it" (Greenberg \& Baron, 2008 p. 234). It can mean employees' relationship, alignment, identification, and engagement with an organization (Djafri \& Noordin, 2017; Hashim, 2010). Hofmann and Stokburger-Sauer (2017) view organizational commitment as contentment and effective emotional affiliation with a job. Mowday et al., (1979 p. 226) note that organizational commitment "involves an active relationship with the organization such that individuals are willing to give something of themselves in order to contribute to the organization's progress". Studies indicate that employees with perceived high commitment take pride in considering themselves a part of an organization (Dam et al., 2017). Hence, organizational commitment can be a form of psychological attachment with the values and norms of the organization (Carmeli, Elizur, \& Yaniv, 2007).

Schermerhorn et al., (2011) identified two dimensions in which employees' organizational commitment can be measured - rational commitment and emotional commitment dimensions. The former reflects feelings that a job serves one's financial, developmental, or professional interests. The latter reflects feelings that what one does is important, valuable, and of benefits to others. Meyer et al., (1993) proposed three dimensions to assess organizational commitment. They include affective, continuance, and normative commitment. These are collectively known as the Three - Components Model (TCM) of organizational commitment. Meyer et al., (1993) say that these components may serve as dimensions to measure employees' level of organizational commitment. This study adapts Meyer et al's., (1993) Three-Component Model (TCM) for some reasons. First, its scale has "generally acceptable psychometric properties in terms of reliability, convergent validity, and construct validity" (Ko et al., 1997 p. 962). Second, its "dimensions accommodate different commitment domain" such as organizational commitment, professional commitment, occupational commitment, career commitment, union commitment, and so forth (Dixit \& Bhati, 2012 p. 35). Third, it is "the most cited work on commitment in organizational behavioural research" (Jaros, 2012 p. 7). Each of the component in the TCM is discussed in the next sub-section.

\section{Affective Commitment}

Affective commitment (AC) is “the strength of a person's desire to work for an organization because he or she agrees with it and wants to do so" (Greenberg \& Baron, 2008 p. 236). It is linked to employee's belief in organizations' core values such as the mission and vision statements (Robbins \& Judge, 2007). Sonar and Paliwal (2018) say that AC involves a show of willingness to exert effort to remain with the organization. Hence, it is a form of employees' emotional attachment to the organization. Researchers (e.g., Meyer \& Allen, 1991; van Gelderen \& Bik, 2016) consider values such as equity in reward distribution, organizational support, delivering quality services, role clarity, and freedom of conflict, decentralization of decision making, and so forth as reasons for affective commitment.

\section{Continuance Commitment}

Meyer et al., (1993) modelled continuance commitment (CC) along Becker's (1960) side-bet theory of commitment. Becker (1960 p. 33) note that commitment is employees' disposition to engage in "consistent lines of activity" as a result of accumulation of "side-bets" that would be lost if the activity is discontinued. Meyer 
and Allen (1991 p. 64) say side-bet occurs when "something of importance to an individual (e.g., pension) becomes contingent upon continued employment". Therefore, $\mathrm{CC}$ can refer to "perceived economic value of remaining with an organization compared to leaving it" (Robbins \& Judge, 2007 p. 80). Research equally indicates that CC measures 'high sacrifices' and 'low alternatives' (Jasos \& Culpepper, 2014 p. 79). This means that employees' CC is not determined only by fear of losing side-bets (e.g., incentives, investments), but also, by low availability of other jobs (Ko et al., 1997; Powell \& Meyer, 2004). Shore et al., (2000) posit that social costs might contribute to employees' side-bets, e.g., friendly co-workers. In essence, CC may be due to fear of losing benefits or perceived lack of alternative jobs (Dixit \& Bhati, 2012; Jaros \& Culpepper, 2014). Therefore, employees may continue with an organization because it is perceived too costly to leave.

\section{Normative Commitment}

Normative commitment deals with the "desires of employees to continue working for an organization because he or she feels the obligations from others to remain" (Greenberg \& Baron, 2008 p.236). The obligation to remain with an organization might be due to ethical or moral reasons (Robbins \& Judge, 2007), or due to thoughts on the perception of co-workers (Meyer \& Allen, 1991). Employees with this form of mindset put into consideration their perceived responsibility to their organizations. Normative commitment can be likened to a "reasoned-action models of behaviour" (Meyer \& Allen, 1991 p. 66), an "indebted obligation" (Jaros, 2007 p. 12), or a form of psychological contract (Rousseau, 1998), where employees belief that their continued stay with an organization is the right thing to do. For instance, employees, whose educational organization have granted scholarship or training skills, may feel it is ethically and morally important to remain with the institution, until the expirations of agreed working terms and conditions. Given the aforementioned types of commitment, organizations are often faced with incessant employees' intention to turnover, actual turnover, absenteeism, redundancy, and so forth. In other instance, employees engage in presenteeism, call in sick or opt for voluntary retirement (Mafukata \& Mudau, 2016). The outcomes of previous studies suggest that spiritual intelligence can be motivating in this regard.

\section{Spiritual Intelligence}

Rego and Cunha (2008 p. 55) note that it may be relevant to avoid "obsession with definition and work from guiding definitions" when examining spirituality. In the current study, the operational definition for spiritual intelligence is "a set of mental capability which contribute to the awareness, integration, and adaptive application of one's existence, leading to such outcomes as deep existential reflection, enhancement of meaning, recognition of a transcendent self, and mastery of spiritual states (King \& DeCicco, 2009 p. 69). Gardner (2000) refers to it as the ninth form of intelligence which is presumed to be an autonomous intelligence based on human inclination to ponder the most fundamental questions of existence. Researchers (e.g., Ogunsola, Fontaine, \& Jan, 2019; Sisk, 2015; Vasconcelos, 2019) posit that it spiritual intelligence can help employees solve every day adaptive problems.

Smith (2014 p. 19) says that King and DeCicco's Spiritual Intelligence and Self-Report Instrument (SISRI-24) "is the most closely tied to the intelligence criteria of Gardner's $(1983,1999)$ " Multiple Intelligence Theory. King and DeCicco's definition satisfy three intelligence criteria:

1. A set of characteristic mental abilities that are distinct from preferred behaviors.

2. The facilitation of adaption and problem solving.

3. Development over a lifespan.

\section{Components of Spiritual Intelligence}

Regardless of employees' spiritual perspective, researchers have found ways to measure spiritual intelligence by advancing some components (Amram \& Dryer, 2007; Emmons, 2000b; Hacker \& Washington, 2017; Wigglesworth, 2006; Zohar \& Marshall, 2000). Chan and Siu (2016) posit that King and DeCicco's SISRI-24 components establish one of the most ecumenical (universal) concepts believed to be valid and worthy to assess spiritual intelligence. The components are core abilities presumably valued across cultures (Emmons, 2000a). Burrow (2005 p. 78) remarks that the components "shift individuals from a state of acting from lower motivations (e.g., greed, anger, fear and self-assertion), to one of an acting, from higher motivations (e.g., cooperation, higher service and exploration)". Hence, the components are expected to be transformative in nature. They are: 


\section{Critical Existential Thinking (CET)}

It is the "capacity to critically contemplate meaning, purpose, and existential or metaphysical issues" (King \& DeCicco, 2009 p. 70). The component predisposes employees to ponder on existential issues such as death, life, or the universe. Within this thinking process, they are able to use intuition to understand people or the world around. Hence, employees are able to view issues, circumstances or events from different perspectives.

\section{Personal Meaning Production (PMP)}

It is the "ability to construct personal meaning and purpose in all physical and mental experiences, including the capacity to create and master a life purpose" (King \& DeCicco, 2009 p. 70). Sisk (2015) argues that an experience of personal meaning often leads to sense of belongingness and fulfilment at the workplace. That is, employees are able to give symbolic meaning to events and circumstances (Zohar \& Marshall, 2000). Ability to give symbolic meaning to issues bring wholeness, direction, wellness, and commitment.

\section{Transcendental Awareness (TA)}

King and DeCicco (2009 p. 71) refer to transcendental awareness as the act of "integrating individual goals with larger ones, such as seeking the well-being of the family, community, humanity or planet". Research indicates that transcendental awareness can deepens love, compassion, and wisdom for community work (Amram, 2009; Milliman \& Bradley-geist, 2017). Hence, it is a spiritual path that recognizes the values of others, as well as that of the self.

\section{Conscious State Expansion (CSE)}

It is "the ability to enter spiritual states of consciousness at one's own discretion" (King \& DeCicco 2009, p. 71). Researchers note that the component is presumed to be the hyper consciousness stage (Mahmood et al., 2018; Ramachandaran et al., 2017). Hence, employees tend to transform from self-centeredness to Godcentredness or others- centeredness (Hacker \& Washington, 2017). Wigglesworth (2006) notes that employees become less-ego driven and are more interested in being of service to others. Humility is a natural outcome of this process, so is courage, patience, and perseverance. Employees can benefit greatly from these qualities.

\section{Relationship between Spiritual Intelligence and Organizational Commitment}

Researchers note that spiritual intelligence can enable employee to better identify and solve practical, existential, and spiritual issues (Feng, Xiong, \& Li, 2017; King \& DeCicco, 2009). Saleem et al., (2017) found that the quest for value and meaningful life through spiritual intelligence are prerequisites that aid problem solving in the workplace. Emmons (2000a) submits that spiritual intelligence deals with both mind and emotions. Thus, it inspires employees towards virtuous behaviors that deepens their commitment in the workplace. Beekun (2012) expresses that commitment can be linked to sacredness when employees see their job as a form of calling, rather than meal ticket. It was argued that once service interaction becomes a form of calling, then, it is easier for employees to view organizational activities as part of their connectedness (commitment) to their organizations (Khaliq \& Ogunsola, 2011; Ogunsola, 2018). Hence, spiritual traits can reflect organizational commitment.

Studies reveal that spiritual intelligence has multi-functional benefits. Akhtar et al., (2015) found that it enables employees to have access to deep meaning, abide to fundamental values in everyday routine, and think out of the box in order to accomplish their desired goals. Vaughan (2002) says it can facilitate task performance because employees are able to use spiritual resources to maneuver work-related challenges. In essence, spiritual intelligence reduces extraneous tensions and authenticates employees' commitment, through re-alignment of values (Mahmood et al., 2018; Osman-Gani et al., 2017). Moreover, it can rekindle their willingness to expressly undertake required workplace activities without difficulties (Vasconcelos, 2019). With the foregoing discussion, it can be anticipated that spiritual intelligence will stimulates organizational commitment. To this end, it can be hypothesized that:

H1: Spiritual intelligence components have positive relationship with organizational commitment. 


\section{Methodology}

\section{Participants}

To test the hypothesis, a group of employees, mainly teachers, in the Peninsular Malaysia were examined. Through a list-based simple random sampling technique, 30 private secondary schools were randomly selected using research randomizer software. The procedures for the survey were explained to schools prior to data collection. 600 respondents were expected to respond to the 42 items survey questionnaire. The expected responses satisfy the sample size threshold ratio of 10:1 for questionnaire items (Frost et al., 2007; Hair et al., 2010; Tsang et al., 2017).

\section{Instruments}

Organizational Commitment: Meyer et al's., (1993) TCM was adapted to profile teachers' commitment. TCM items were tapped on a five-point Likert scale of $(1=$ strongly disagree to $5=$ strongly agree $)$. TCM was analysed as a second-order construct with three dimensions. They are affective, normative, and continuance commitment. Each dimension has six items respectively. Item example include: "the organization has a great deal of personal meaning for me'.

Spiritual Intelligence: King and DeCicco's (2009) SISRI-24 items was adapted as a second-order construct with four dimensions (e.g., CET - 7 items, PMP - 5 items, TA -7 items, CSE - 5 items). Each dimension is anchored on a five-point Likert type scale of $(0=$ 'not at all true of $m e$ ' and $4=$ 'completely true of $m e$ '). Item example include: "I have spent time contemplating the purpose or reason for my existence".

\section{Data Collection and Analysis}

Data was collected electronically. Antunes et al., (2017 p. 5) contend that electronic means "guarantees informed consent and data confidentiality". Moreover, "more reliable data are likely to result since the respondents can go back and forth, and easily change a response" (Sekaran, 2003 p. 250). Data collection was between May and October 2019. IBM SPSS 24.0 software was used for demography frequencies and EFA. AMOS 24.0 software was used for CFA data validation and SEM hypothesis testing.

\section{Results}

\section{Response Rate}

Out of 600 expected responses, 35 respondents participated in the pilot study instrument adaptation stage. Main study had 565 participants, out of which 526 responses were received, giving a response rate of $93.10 \%$. 16 responses were invalidated with respect to Ron et al., (2015 p. 688) recommendations on "straight-lining or satisficing" regarding online survey. So, only 510 valid usable responses were analysed. This gave a usable response rate of $96.96 \%$. The high response rate was due to several follow-up measures (e.g., phone calls, emails, visitations). The convenience of responding to an electronic questionnaire also contributed to the high response rate.

\section{Social - Demographic Characteristics (Main Study)}

Participants are mostly aged between 30 and 45 years $(M=2.30 ; \mathrm{SD}=1.01)$. With respects to male in Table 1 , $72(14.1 \%)$ and 234 (45.9\%) females have master's and bachelor's degree respectively, 165 (32.4\%) female have spent over 10 years in the teaching profession, while $151(29.6 \%)$ were married.

The social-demographic table demonstrates an unequal representation of gender as teachers. It can be inferred that there are more female teachers than male in the Malaysian education system. This outcome is consistent with the report from Malaysian Ministry of Education (MOE, 2018 p. 26). 
Table 1. Social - Demographic Characteristics of Respondents

\begin{tabular}{|c|c|c|c|c|c|c|}
\hline & \multicolumn{4}{|c|}{ Gender } & & \\
\hline & \multicolumn{2}{|c|}{ Male } & \multicolumn{2}{|c|}{ Female } & \multicolumn{2}{|c|}{ Total } \\
\hline & Count & $\%$ & Count & $\%$ & Count & $\%$ \\
\hline \multicolumn{7}{|l|}{ Age } \\
\hline Below 30 & 34 & 6.7 & 70 & 13.7 & 104 & 20.4 \\
\hline $30-45$ & 55 & 10.8 & 190 & 37.3 & 245 & 48.0 \\
\hline $46-50$ & 11 & 2.2 & 52 & 10.2 & 63 & 12.4 \\
\hline Above 50 & 30 & 5.9 & 68 & 13.3 & 98 & 19.2 \\
\hline \multicolumn{7}{|l|}{ Education } \\
\hline Master & 22 & 4.3 & 72 & 14.1 & 94 & 18.4 \\
\hline Bachelor & 39 & 7.7 & 234 & 45.9 & 273 & 53.6 \\
\hline Others & 69 & 13.5 & 74 & 14.5 & 143 & 28.0 \\
\hline \multicolumn{7}{|l|}{ Work Experience } \\
\hline Below 2 years & 10 & 1.9 & 15 & 2.9 & 25 & 4.8 \\
\hline $2-5$ years & 41 & 8.0 & 121 & 23.7 & 162 & 31.8 \\
\hline $6-10$ years & 32 & 6.3 & 79 & 15.5 & 111 & 21.8 \\
\hline Above 10 years & 47 & 9.2 & 165 & 32.4 & 212 & 41.6 \\
\hline \multicolumn{7}{|l|}{ Marital Status } \\
\hline Single & 75 & 14.7 & 182 & 35.7 & 257 & 50.4 \\
\hline Married & 37 & 7.3 & 151 & 29.6 & 188 & 36.9 \\
\hline Others & 18 & 3.5 & 47 & 9.2 & 65 & 12.7 \\
\hline Religion & 130 & 25.5 & 380 & 74.5 & 510 & 100 \\
\hline
\end{tabular}

Source: Field Survey (2019).

\section{Questionnaire Characteristics}

From Table 2, the average mean score for organizational commitment is $M=3.94, S D=0.90$. Respondents average mean score for spiritual intelligence shows $M=3.07, S D=0.85$. The internal reliability assessment $(\alpha=$ $0.885)$ shows strong indications that questionnaire items have good internally consistency.

Table 2. Average Mean, Standard Deviations and Reliability

\begin{tabular}{lcccc}
\hline Constructs & Items & Mean & SD & Alpha $(\alpha)$ \\
\hline Organizational Commitment (OC) & 18 & 3.94 & 0.90 & 0.885 \\
Spiritual Intelligence (SQ) & 24 & 3.07 & 0.85 & 0.920 \\
\hline Source: SPSS Output Table (2019). & & & &
\end{tabular}

Hence, each item actually measures what it intends to measure. Values of skewness and kurtosis (not shown here due to space) revealed that most questionnaire items fell within the acceptable value range of $z= \pm 1.96$ ( $\mathrm{p}<$ 0.05) (Pallant, 2007). The outcomes of this preliminary analysis suggest that data are normally distributed.

\section{Exploratory Factor Analysis (EFA)}

The questionnaire used was adapted. So, principal component analysis (PCA) was employed for factor analysis. Prior to performing PCA, the suitability of data for factor analysis was examined. Inspection of correlation matrix revealed the presence of coefficients $(r \geq 0.3)$. KMO was 0.851 and 0.890 for OC and SQ respectively, exceeding the recommended value of 0.6 (Kaiser, 1974). Bartlett's Test of Sphericity $(p<0.05)$ reached statistical significance (Bartlett, 1954; Tabachnick \& Fidell, 2007), supporting the factorability of the correlation matrix. The adequacy of the data was equally proven with items having communalities values above 0.3 recommended threshold (Antunes et al., 2017; Pallant, 2007). These outcomes show that the study can proceed with data factorability. 
To this end, varimax normalized rotated component matrix retained a three-factor solution for OC:- AC $(\alpha=$ $0.77), \mathrm{CC}(\alpha=0.84)$, and NC $(\alpha=0.81)$. Each factor has six items respectively (EFA Table not shown due to space). Rotation maintained a four-factor solution for SQ, but with 19 items:- CET (6 items; $\alpha=0.84$ ), PMP (5 items; $\alpha=0.83$ ), TA (4 items; $\alpha=0.84$ ), and CSE (4 items; $\alpha=0.79$ ). Cronbach (1951) recommends that an alpha $(\alpha)$ value of $\geq 0.6$ is adequately reasonable as internal reliability. Given the Cronbach's Alpha value for each sub-construct, it can be established that the factored solutions demonstrate acceptable measurement internal reliability properties (Guillemin et al., 1993; Nunnally, 1978). Theoretically, this provides evidence that further statistical analysis can be carried out.

\section{Confirmatory Factor Analysis (CFA)}

Validation of the measurement model was carried out through Maximum Likelihood Method (Bentler, 1983; Zainudin, 2014), using key GOF indices. The outcome revealed $\chi^{2} / d f$ ratio $(997.341 / 547)=1.823$, RMSEA (0.057), and CFI (0.903). These outcomes are within reasonable recommended thresholds (Browne \& Cudeck, 1993; Hair et al., 2010; Marsh \& Hocevar, 1985). This implies that the measurement model has good data-fit.

Though, an item each was dropped from both SQ and OC because of low estimate loadings. Still, a careful examination of the measurement model for construct validity through convergent validity, discriminate validity, construct reliability (CR), and average variance extracted (AVE), shows that the measurement model is supported (see Table 3). The total CFA items reduced to 35. Their standardized estimate loadings were above 0.5 and $\leq 0.85$. In the overall, CFA assessment outcomes are within acceptable ranges to support construct validity (Byrne, 2010; Kline, 2011; Schumacker \& Lomax, 2012). These results provide further validity for the measurement model.

Table 3. CFA Validity and Reliability Assessment Test

\begin{tabular}{|c|c|c|c|c|c|}
\hline & $\mathbf{C R}$ & AVE & $(\alpha)$ & $\mathrm{OC}$ & SQ \\
\hline$\overline{\mathrm{OC}}$ & 0.94 & 0.50 & 0.94 & $\overline{1}$ & $0.46^{* *}$ \\
\hline \multirow[t]{2}{*}{ SQ } & 0.95 & 0.51 & 0.93 & $0.68 *$ & 1 \\
\hline & & & \multicolumn{2}{|c|}{ Threshold } & Remarks \\
\hline \multirow{3}{*}{\multicolumn{3}{|c|}{$\begin{array}{l}\text { Construct Reliability }(\mathrm{CR}) \\
\text { Average Variance Extracted (AVE) } \\
\text { Cronbach's Alpha }(\alpha)\end{array}$}} & \multicolumn{2}{|c|}{$\mathrm{CR} \geq 0.70$} & Supported \\
\hline & & & \multicolumn{2}{|c|}{$\mathrm{AVE} \geq 0.50$} & Supported \\
\hline & & & \multicolumn{2}{|c|}{$\alpha>0.60$} & Supported \\
\hline \multicolumn{3}{|c|}{ Convergent Validity } & & & Supported \\
\hline \multicolumn{3}{|c|}{ Discriminant Validity } & & & Supported \\
\hline
\end{tabular}

\section{Structural Equation Modeling (SEM)}

Having established the construct validity, the structural model was assessed in order to provide empirical justifications for its hypothesis. The outcome of GOF indices is similar with those of CFA (see Figure1). Researchers contend that similarities in CFA and SEM indices indicate support for the proposed hypothesized structural model. It also shows that the structural model represented the sampled population (Byrne, 2010; Hair et al., 2010; Kline, 2011). Therefore, the structural model is data fit and theoretically valid.

In Table 3, SQ and OC correlated positively $(r=0.68)$. In Figure 1, parameters standardized path estimates for the relationship between SQ and OC is $\left(H_{1}: \beta=0.86, p<0.05\right)$. This shows that spiritual intelligence has a significant positive relationship with organizational commitment. In other words, employees with heightened spiritual intelligence are likely to show higher level of organizational commitment. This result implies that $H_{l}$ is significantly valid and accepted. 


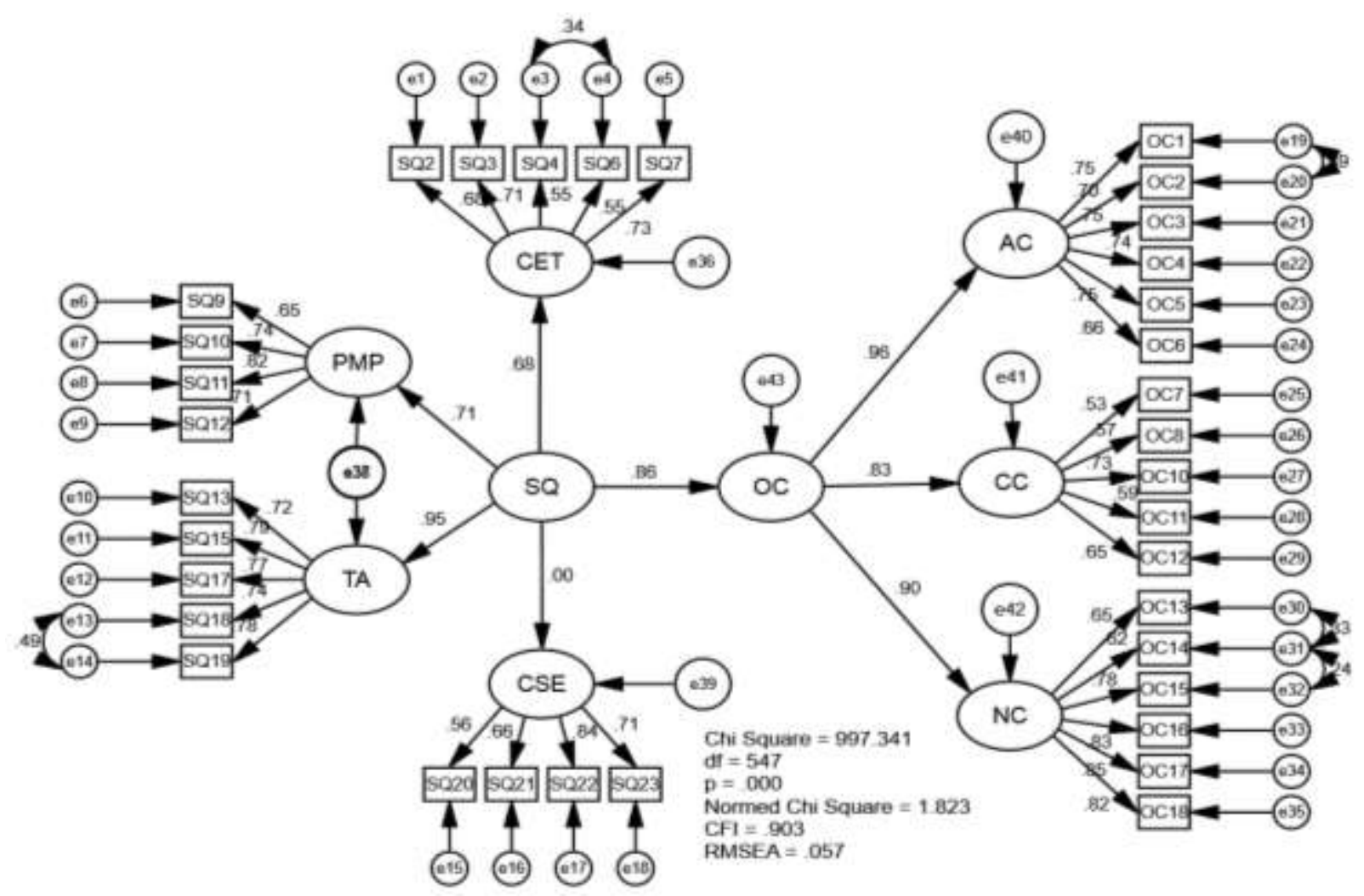

Figure 1. Structural Model

\section{Discussion}

This paper focuses on testing the relationship between spiritual intelligence and organizational commitment. Scholars established that intelligence aids solving adaptive problems (Bhullar, 2015; Sternberg, 1997). Given the theory of multiple intelligence (Gardner, 1999), spiritual intelligence can function appropriately in this regard. The outcome of this paper supports this proposition. Findings in this paper is also consistent with previous research.

Spiritual intelligence is about "harnessing spiritual resources to solve problems" (Fontaine, 2018 p. 2). Hence, it is the ability to behave with compassion and wisdom while maintaining inner and outer peace (equanimity) regardless of the circumstances (Wigglesworth, 2006). This portends that spiritual intelligence is an intelligence of the soul, which employees may develop to nourish the inner self, in order to develop a deep sense of meaning towards task performance (Awais et al., 2015; Kumari \& Chahal, 2017; Soha et al., 2016).

Ogunsola et al., (2019 p. 342) note that spiritual intelligence is a "form of intelligence which instils a reserved and heightened state of consciousness in an individual to feel, interact, and behave with calmness irrespective to environmental exigencies". In this regard, spiritual intelligence can re-align employees' perception beyond materialism, physical benefits or tokens (Fesharaki, 2019; Sisk, 2015). So, employees tend to cope with strenuous workplace or life circumstances for positive organizational commitment.

\section{Implications of the Study}

The paper contributes to the body of knowledge by theoretically establishing a link between spiritual values and employees' everyday organizational activities. The study's outcomes suggest some implications to HR policies. For instance, HR manger can encourage employees to develop spiritual intelligence to augment policies on compensation. That is spiritual intelligence can act as motivation to employees. Hence, it can transcend them beyond pain, suffering or ego associated with performing a task. In another way, spiritual intelligence can aid HR policies on employees' training. It can train employees to be selfless, cautious, and contended with 
organizational welfare packages. Practically, it can cultivate a higher level of morals and ethics in employees. In this regard, both employers and employees can see each other as collaborator in quest for a common goal organizational commitment.

\section{Conclusion}

This paper examined the relationship between spiritual intelligence and organizational commitment. Findings revealed that employees who are heightened with spiritual intelligence tends to show higher commitment towards task performance. This suggests that organizations can sustain employees' commitment by tapping into their spiritual values to enhance workplace activities. Employees may also benefit in terms of spiritual, emotional, physical, and psychological wellness of the self.

\section{Limitation and Future Areas of Study}

Being a cross-sectional study, it is likely that the outcome is subjected to common method bias. Future study may consider longitudinal approach to verify this result. A purely quantitative method was employed, other research may adopt a mix-mode option to ascertain the generalizability of this study. In addition, socialdemographic factors e.g., age and gender are controlled in this study. Future research may investigate the moderating role of these factors on the relationship between spiritual intelligence and organizational commitment.

\section{References}

Akhtar, S., Arshad, M. A., Mahmood, A., \& Ahmed, A. (2015). Spiritual Quotient and ethical values towards organizational sustainability. International Letters of Social and Humanistic Sciences, 58(2001), 1-7. https://doi.org/10.18052/www.scipress.com/ILSHS.58.1

Amram, Y. (2009). The contribution of emotional and spiritual intelligences to effective business leadership. (Unpublished doctoral dissertation). Institute of Transpersonal Psychology, Palo Alto, CA.

Amram, Y., \& Dryer, C. (2007). The development and preliminary validation of the Integrated Spiritual Intelligence Scale (ISIS). Unpublished manuscript.

Antunes, R. R., Silva, A. P., \& Oliveira, J. (2017). Spiritual Intelligence Self-Assessment Inventory: Psychometric properties of the Portuguese version of SISRI-24. Journal of Religion, Spirituality and Aging, 30(1), 12-24. https://doi.org/10.1080/15528030.2017.1324350

Awais, M., Malik, M. S., \& Qaisar, A. (2015). A review: The job satisfaction act as mediator between spiritual intelligence and organizational commitment. International Review of Management and Marketing, 5(4), 203-210.

Bartlett, M. S. (1954). A Note on the multiplying factors for various Chi Square approximations. Journal of the Royal Statistical Society, 16, 296-298.

Becker, H. (1960). Notes on the Concept of Commitment. American Journal of Sociology, 66(1), 32-40.

Beekun, R. I. (2012). Character centered leadership: Muhammad (p) as an ethical role model for CEOs. Journal of Management Development, 31(10), 1003-1020. https://doi.org/10.1108/02621711211281799

Bentler, P. M. (1983). Simultaneous equation sysyems as momnet structure models - With an Introduction to Latent Variable Models. Journal of Econometrics, 22, 13-42.

Bhullar, A. (2015). The growth of spiritual intelligence. Indian Journal of Educational Studies: An Interdisciplinary Journal, 2(1), 122-131.

Browne, M. W., \& Cudeck, R. (1993). Alternative ways of accessing model fit. In K. A. Bollen \& J. S. Long (Eds.), Testing structural equation models (pp. 136-162). Newbury Park, CA: Sage.

Burrows, L. (2005). SQ: Connecting with our Spiritual Intelligence. Gifted and Talented International, 20(2), 78-80. https://doi.org/10.1080/15332276.2005.11673456

Byrne, B. M. (2010). Structural equation modeling with AMOS: Basic concepts, applications and programming. New York, NY: Taylor and Francis Group LLC.

Carmeli, A., Elizur, D., \& Yaniv, E. (2007). The theory of work commitment: a facet analysis. Personnel Review, 36(4), 638-649. https://doi.org/10.1108/00483480710752849

Castro-Casal, C., Vila-Vázquez, G., \& Pardo-Gayoso, Á. (2019). Sustaining affective commitment and extrarole service among Hospitality Employees: Interactive effect of empowerment and service training. Sustainability, 11(4092), 1-16. https://doi.org/10.3390/su11154092

Chan, A. W. Y., \& Siu, A. F. Y. (2016). Application of the spiritual intelligence self-report inventory (SISRI- 
24) among Hong Kong university students. International Journal of Transpersonal Studies, 1(1), 1-12.

Cronbach, L. J. (1951). Coefficient alpha and the internal structure of tests. Psychometrika, 16(3), $297-334$.

Dam, K. Van, Vuuren, T. Van, \& Kemps, S. (2017). Sustainable employment: The importance of intrinsically valuable work and an age-supportive climate. The International Journal of Human Resource Management, 28(17), 2449-2472. https://doi.org/10.1080/09585192.2015.1137607

Dixit, V., \& Bhati, M. M. (2012). A Study about employee commitment and its impact on sustained productivity in Indian auto-component industry. European Journal of Business and Social Sciences, 1(6), 34-51.

Djafri, F., \& Noordin, K. (2017). The impact of workplace spirituality on organizational commitment: a case study of Takaful agents in Malaysia. Humanomics, 33(3), 384-396. https://doi.org/10.1108/H-02-20170018

Emmons, R. A. (2000a). Is spirituality an intelligence? motivation, cognition, and the psychology of ultimate concern. International Journal for the Psychology of Religion, 10(1), 3-26. https://doi.org/10.1207/S15327582IJPR1001_2

Emmons, R. A. (2000b). Spirituality and intelligence: Problems and propects. The International Journal for the Psychology of Religion, 10(1), 57-64. https://doi.org/10.1207/S15327582IJPR1001

Feng, M., Xiong, X., \& Li, J. (2017). Spiritual intelligence scale--Chinese form: Construction and initial validation. Current Psychology, 1(Sep), 1-10. https://doi.org/10.1007/s12144-017-9678-5

Fesharaki, F. (2019). Entrepreneurial passion, self-efficacy, and spiritual intelligence among Iranian SME owner - managers. Psychological Studies, (July). https://doi.org/10.1007/s12646-019-00507-0

Fontaine, R. (2018). Developing spiritual intelligence: Some new evidence. International Journal of Islamic Management and Business, 7(1), 95-107.

Freeman, E. R. (1983). Stockholders and stakeholders: A new perspective on corporate governance. California Management Review, 25(3), 88-106.

Frost, M. H., Reeve, B. B., Liepa, A. M., Stauffer, J. W., Hays, R. D., \& Mayo, F. P. M. C. (2007). What is sufficient evidence for the reliability and validity of patient-reported outcome measures? Value in Health, 10(Supplement 2), 94-105.

Gardner, H. (1983). Frames of mind: The theory of multiple intelligences. New York, NY: Basic Books.

Gardner, H. (1999). Intelligence reframed: Multiple intelligences for the new millenium. New York: Basic Books.

Gardner, H. (2000). A Case against spiritual intelligence. International Journal for the Psychology of Religion, $10(1), 27-34$.

Greenberg, J., \& Baron, R. (2008). Behavior in organizations (9th ed.). New Jersey: Prentice Hall.

Guillemin, F., Bombardier, C., \& Beaton, D. (1993). Cross-cultural Adaptation of Health-related quality of life measures: Literature review and proposed guidelines. Journal of Clinical Epidemiology, 46(12), 14171432.

Hacker, S. K., \& Washington, M. (2017). Spiritual intelligence: going beyond IQ and EQ to develop resilient leaders. Global Business and Organizational Excellence, (March/April), 21-28. https://doi.org/10.1002/joe. 21777

Hair, J. F. (Jr)., Black, W. C., Babin, B. J., \& Anderson, R. E. (2010). Multivariate data analysis (7th ed.). New Jersey: Prentice Hall.

Hashim, J. (2010). Human resource management practices on organisational commitment: the Islamic perspective. Personnel Review, 39(6), 785-799. https://doi.org/10.1108/00483481011075611

Hofmann, V., \& Stokburger-Sauer, N. E. (2017). The impact of emotional labor on employees' work-life balance perception and commitment: A study in the hospitality industry. International Journal of Hospitality Management, 65, 47-58. https://doi.org/10.1016/j.ijhm.2017.06.003

Hunsaker, W. D. (2016). Spiritual leadership and organizational citizenship behavior: relationship with Confucian values. Journal of Management, Spirituality \& Religion, 13(3), 206-225. https://doi.org/10.1080/14766086.2016.1159974

James, P., Lee, P., \& Sybille, S. (2002). Redefining the Corporation: Stakeholder management and organizational Wealth. Stanford, CA: Stanford University Press.

Jaros, S. (2007). Meyer and Allen model of organizational commitment: measurement issues. The Icfai Journal of Organizational Behavior, VI(4), 7-26.

Jaros, S., \& Culpepper, R. A. (2014). An analysis of Meyer and Allen's continuance commitment construct. Journal of Management \& Organization, 20(1), 79-99. https://doi.org/10.1017/jmo.2014.21

Kaiser, H. F. (1974). An index of factorial simplicity. Psychometrika, 39(1), 31-36.

Kalantarkousheh, S. M., Sharghi, N., Soleimani, M., \& Ramezani, S. (2014). The Role of spiritual intelligence on organizational commitment in employees of universities in Tehran province, Iran. Procedia - Social and Behavioral Sciences, 140(2008), 499-505. https://doi.org/10.1016/j.sbspro.2014.04.460

Kaur, G., \& Singh, R. P. (2013). Spiritual intelligence of prospective engineers and teachers in relation to their gender, locality and family status. Educationia Confab, 2(1), 27-43. 
Khaliq, A., \& Ogunsola, O. K. (2011). An empirical assessment of Islamic leadership principles. International Journal of Commerce and Management, 21(3), 291-318. https://doi.org/10.1108/10569211111165325

King, D. B., \& DeCicco, T. L. (2009). A Viable model and self-report measure of spiritual intelligence. International Journal of Transpersonal Studies, 28(1), 68-85.

Kline, R. B. (2011). Principles and practice of structural equation modeling (3rd ed.). New York, NY: The Guildford Press.

Ko, J., Price, J. L., \& Mueller, C. W. (1997). Assessment of Meyer and Allen's three-component model of organizational commitment in South Korea. Journal of Applied Psychology, 82(6), 961-973.

Kumari, M., \& Chahal, D. (2017). Spiritual intelligence of secondary school teachers in relation to their demographic variables. International Journal of Academic Research and Development, 2(4), 462-465.

Mafukata, M. A., \& Mudau, A. V. (2016). Exploring teacher mass resignation and early retirement from public schools. Dirasat, Human and Social Sciences, 43, 2243-2255.

Mahmood, A., Arshad, M. A., Ahmed, A., Akhtar, S., \& Khan, S. (2018). Spiritual intelligence research within human resource development: A thematic review. Management Research Review, 41(8), 987-1006. https://doi.org/10.1108/MRR-03-2017-0073

Marghzar, S. H., \& Marzban, A. (2018). The relationship between spiritual intelligence and efficacy among Iranian EFL teachers. Theory and Practice in Language Studies, 8(1), 67-73.

Marsh, H. W., \& Hocevar, D. (1985). Application of confirmatory factor analysis to the study of self-concept: First- and higher order factor models and their invariance across groups. Psychological Bulletin, 97(3), $562-582$.

Meyer, J. P., \& Allen, N. J. (1991). A three-component model conceptualization of organizational commitment. Human Resource Management Review, 1(1), 61-89. https://doi.org/10.1016/1053-4822(91)90011-Z

Meyer, J. P., Allen, N. J., \& Smith, C. A. (1993). Commitment to organizations and occupations: Extension and test of a three-component conceptualization. Journal of Applied Psychology, 78(4), 538-551. https://doi.org/10.1037/0021-9010.78.4.538

Meyer, J. P., Stanley, D. J., Herscovitch, L., \& Topolnytsky, L. (2002). Affective, continuance and normative commitment to the Organization : a meta-analysis of antecedents, correlates and consequences. Journal of Vocational Behavior, 61, 20-52. https://doi.org/10.1006/jvbe.2001.1842

Milliman, J., \& Bradley-geist, J. C. (2017). The implications of workplace spirituality for person - environment fit theory. Psychology of Religion and Spirituality, 9(1), 1-12.

MOE. (2018). Education planning and research division. Private Education Division. Ministry of Education. Retrieved from https://www.moe.gov.my/index.php/menumedia/media-cetak/penerbitan/terbitan/bukuinformasi/1587-quick-facts-2018-malaysia-educational-statistics-1/file

Mowday, R. T., Steers, R. M., \& Porter, L. W. (1979). The measurement of organizational commitment. Journal of Vocational Behavior, 14, 224-247.

Nunnally, J. C. (1978). Psychometric theory. New York: McGraw-Hill.

Ogunsola, K. O. (2018). Servant leadership: Developing an Islamic performance appraisal instrument for Muslim managers. Malaysian Management Review, 53(1), 55-76.

Ogunsola, K. O., Fontaine, R., \& Jan, M. T. (in press). Impact of surface acting and deep acting techniques on teachers' organizational commitment. PSU Research Review, (In press). https://doi.org/10.1108/PRR-102019-0031

Ogunsola, K. O., Fontaine, R., \& Jan, M. T. (2019). A cross-cultural adaptation and psychometric validation of SISRI-24 among Malaysian teachers. Advances in Social Sciences Research Journal, 6(10), 340-352. https://doi.org/10.14738/assrj.610.7243

Osman-Gani, A., Anwar, M. A., \& Hamid, Z. A. (2017). Impacts Of Emotional Intelligence And Spiritual Intelligence On Leadership Effectiveness Mediated By Personal Values: A Conceptual Framework. Journal of Islamic Management Studies, (1), 43-53. Retrieved from http://publications.waim.my/index.php/jims/article/view/7

Osman-Gani, A. M., \& Hassan, Z. (2018). Impact of spiritual and cultural intelligence on leadership effectiveness: a conceptual analysis. Journal of Islamic Management Studies, 2(1), 12-23. https://doi.org/10.24961/j.tek.ind.pert.2018.28.1.61

Othman, A. K., \& Abas, M. K. (2017). The moderating role of spiritual intelligence on the relationship between job stress and job performance of employees in abanking sector. Journal of Islamic Management Studies, $1(1), 89-103$.

Pallant, J. (2007). SPSS survival manual: A step-by-step guide to data analysis using SPSS for Windows (version 15) (3rd ed.). Australia, Allen \& Unwin.

Pluta, A., \& Rudawska, A. (2016). Holistic approach to human resources and organizational acceleration. Journal of Organizational Change Management, 29(2), 293-309. https://doi.org/10.1108/JOCM-112014-0210

Powell, D. M., \& Meyer, J. P. (2004). Side-bet theory and the three-component model of organizational 
commitment. Journal of Vocational Behavior, 65, 157-177.

Price, J. L. (1997). Handbook of organizational measurement. International Journal of Manpower, 18(4/5/6), 305-558. https://doi.org/10.2307/2063214

Ramachandaran, S. D., Krauss, S. E., Hamzah, A., \& Idris, K. (2017). Effectiveness of the use of spiritual intlligence in women academic leadership practice. International Journal of Educational Management, 31(2). https://doi.org/http://dx.doi.org/10.1108/MRR-09-2015-0216

Rego, A., \& Pina e Cunha, M. (2008). Workplace spirituality and organizational commitment: an empirical study. Journal of Organizational Change Management, 21(1), 53-75. https://doi.org/10.1108/09534810810847039

Robbins, S. P., \& Judge, T. A. (2007). Organizational behaviour (12th ed.). Pearson, NJ: Prentice Hall.

Ron, D. H., Honghu, L., \& Arie, K. (2015). Use of internet panels to conduct surveys. Behavioral Research Methods, 47(July), 685-690. https://doi.org/10.3758/s13428-015-0617-9

Roof, R. A., Bocarnea, M. C., \& Winston, B. E. (2017). The spiritual engagement instrument. Asian Journal of Business Ethics. https://doi.org/10.1007/s13520-017-0073-y

Rousseau, D. M. (1998). The "problem" of the psychological contract considered. Journal of Organizational Behavior, 19, 665-671.

Saleem, Q., Singh, R., \& Singh, B. (2017). A study of spiritual intelligence of teacher edocators. International Journal of Current Multidisciplinary Studies, 3(4), 697-701.

Schermerhorn, J. R. (Jr)., Hunt, J. G., Osborn, R. N., \& Uhl-Bien, M. (2011). Organizational behavior (11ed ed.). Asia: Wiley.

Schumacker, R. E., \& Lomax, R. G. (2012). A beginner's guide to structural equation modeling (3rd ed.). Taylor \& Francis.

Sekaran, U. (2003). Research methods for business: a skill building approach (4th ed.). John Wiley \& Sons, Inc.

Shore, L. M., Tetrick, L. E., Shore, T. H., \& Barksdale, K. (2000). Construct validity of measures of Becker 's Side Bet Theory, 444, 428-444. https://doi.org/10.1006/jvbe.1999.1749

Sisk, D. A. (2015). Spiritual intelligence: developing higher consciousness revisited. Gifted Education International, 32(3), 1-15. https://doi.org/10.1177/0261429415602567

Smith, B. (2014). Spiritual Intelligence: Definitions and Measurements. Fielding Graduate University. Retrieved from http://pre-beta.com/clients/zampella/wp-content/uploads/2014/08/SpiritualIntelligenceBarrySmithPaper.pdf

Soha, M. H., Osman, A., Nizam, S., Abdullah, S., \& Ramlee, N. F. (2016). The relationship of work influence, sense of community and individual spirituality towards organizational performance. Procedia Economics and Finance, 35(October), 591-596. https://doi.org/10.1016/S2212-5671(16)00072-1

Sonar, P., \& Paliwal, M. (2018). The effect of emotional labour on organizational commitment among call centre customer service representatives. International Journal of Management, 9(2), 93-102.

Sternberg, R. J. (1997). The Concept of intelligence and its Role in lifelong learning and success. American Psychologist, 52(10), 1030-1037.

Tabachnick, B. G., \& Fidell, L. S. (2007). Using multivariate statistics (5th ed.). Boston: Pearson Education.

Tsang, S., Royse, C. F., \& Terkawi, A. S. (2017). Guidelines for developing, translating, and validating a questionnaire in perioperative and pain medicine. Saudi Jounal of Anaesthesia, 11(1), 1-15. https://doi.org/10.4103/sja.SJA_203_17

Upadhyay, S. (2017). Can spiritual intelligence influence research performance in higher education? Framework for human resource development in higher education. Administratie Si Management Public, 28, 153-173.

van Gelderen, B. R., \& Bik, L. W. (2016). Affective organizational commitment, work engagement and service performance among police officers. Policing: An International Journal of Police Strategies \& Management, 39(1), 206-221. https://doi.org/10.1108/PIJPSM-10-2015-0123

Vasconcelos, A. F. (2019). Spiritual intelligence: A theoretical synthesis and work-life potential linkages. International Journal of Organizational Analysis. https://doi.org/10.1108/IJOA-04-2019-1733

Vaughan, F. (2002). What is spiritual intelligence? Journal of Humanistic Psychology, 42(2), 16-33. https://doi.org/10.1177/0022167802422003

Wigglesworth, C. (2006). Why spiritual intelligence is essential to mature leadership. Integral Leadership Review, 6(3). Retrieved from http://integralleadershipreview.com/5502-feature-article-why-spiritualintelligence-is-essential-to-mature-leadership/

Zainudin, A. (2014). A handbook on SEM for academicians and practitioners. The step by step practical guides for the beginners. Selangor: MPWS Rich Resources.

Zohar, D., \& Marshall, I. (2000). SQ-Spiritual Intelligence: The ultimate intelligence. London: Bloomsbury Publishing. 